\title{
Profit Maximization of Magdalena Dairy Raisers Association's Dairy Products in Magdalena, Laguna
}

\author{
Rolan J. Malvar ${ }^{a}$, Joshua I. Jao ${ }^{b}$, Exequiel Lencer T. Llobrera ${ }^{c}$, Marjorie B. Torres ${ }^{\mathrm{d}}$ \\ ${ }^{\text {a }}$ Chief, Extension Management Office, Office of the Vice President for Research, Extension, and Development, Assistant \\ Professor, Department of Mathematics and Statistics, College of Science, Polytechnic University of the Philippines - Sta. \\ Mesa, Manila \\ b.c.dPolytechnic University of the Philippines - Sta. Mesa, Manila \\ Email: ${ }^{a}$ rjmalvar@pup.edu.ph
}

Article History: Received: 10 November 2020; Revised 12 January 2021 Accepted: 27 January 2021; Published online: 5 April 2021

\begin{abstract}
This research demonstrates the use of linear programming in maximizing the profit. It applies the concept of simplex method; a method in linear programming to solve industrial problems that aims to maximize the profit. The Magdalena Dairy Raisers Association specializes in production of dairy products. Three different varieties of dairy products were observed. The data was simulated using MATLAB; a fourth-generation programming language and numerical analysis environment that creates data visualization and user interfaces (UI), calculates matrices, and develops and runs algorithms. The results show that using the Linear Programming Model, we obtain the total revenue of each dairy product with an increase of $108.17 \%$ for Fresh Milk, $12.10 \%$ for Choco Milk, and 35.95\% for Milk O Jel from their previous revenue. As a result, we achieved our goal to maximize the net profit with a total increase of $151.16 \%$.
\end{abstract}

Keywords: Linear Programming, Simplex Method, MATLAB, MADRA

\section{Introduction}

Profit Maximization is one of several plans of any business, for them to reach a certain quota or somehow, to reach higher than their goal. It is processed by firms for them to determine the prices they're going to implement and output level that returns the greatest profit either in the short run or long run. Linear programming is a subset of Mathematical Programming that is concerned with efficient allocation of limited resources to known activities with the objective of meeting a desired goal of maximization of profit or minimization of cost. Although there is tendency to think that Linear Programming which is a subset of operations research has a recent development, but there is really nothing new about the idea of maximization of profit in any organization setting i.e. in a production company or manufacturing company.

In optimizing the profit, there are several of linear programming models to use, but we have sought a model that suits the situation of many companies, association and industry in the Philippines, having minimal profit of theirbusinesses. We choose the

association for our study. Here, we introduce Simplex Method as the method used in maximizing their profit without sacrificing their money budget for their cost of resources. The two main profit maximization methods used are Marginal Cost-Marginal Revenue Method and Total Cost-Total Revenue Method [1].

Profit maximization has advantage and disadvantage. Taking too much risks may bring the company to a sudden loss. Profit maximization strategy can help the company to reach a certain goal in their income. Profit maximization opens all many assumptions [2].

\section{Research Paradigm}

This study will help the Magdalena Dairy Raisers Association (MADRA) to maximize their profit based on the cost. This study aims to develop a Linear Programming model to help the cooperative in deciding which dairy products; it must give more attention to achieve a highest profit. 


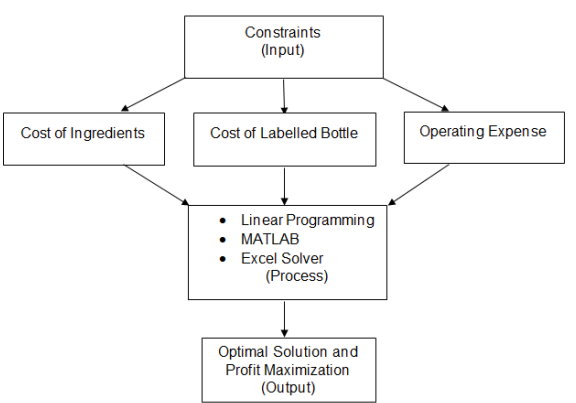

Fig 1: Research Paradigm

The researchers want to enhance their knowledge in developing Linear Programming Model. And lastly, this study will also be beneficial to many researchers for their own work, and to other firms that also have a dairybased products as their business, and not only to dairy-based product companies but for more than a hundred kind of businesses most especially in the province of Laguna which has an approximated 3,035,000 number of population.

\section{Scope and Limitation}

The study focuses on maximizing the profit of Magdalena Dairy Raisers Association (MADRA). The cooperative is known in making dairy products. They produce Choco milk, Fresh Milk, Milk O Jell, Yogurt drink, Yogurt Mix, Kesong Puti and Ice Candy. All of these are carabao's milk-based products. The products that we consider in our research are Choco Milk, Fresh Milk, and Milk O Jell since these products are the most in demand in the market. We consider the cost in production, demand, labor, and other expenses as basis to maximize their profit. The data of this research is limited only for 10 months (20-times production) starting from March to December 2017.

Table 1: Ingredients and Its price

\begin{tabular}{|l|l|}
\hline Carabao's Milk & P55/L \\
\hline Sugar & P47/KG \\
\hline Water & P25/20L \\
\hline Cadburry & P420/KG \\
\hline Cornstarch & P83.30/KG \\
\hline Skimmilk & P170/KG \\
\hline Don Frank & P92.65/250 G \\
\hline Vanilla & P32/20 ML \\
\hline Food Coloring & $\mathrm{P} 39 / 20 \mathrm{ML}$ \\
\hline
\end{tabular}

Table 2: Ingredients Needed in Making $9600 \mathrm{ml}$ of Choco Milk

\begin{tabular}{|l|l|}
\hline Carabao's Milk Used & 5L \\
\hline Cornstarch Used & $80 \mathrm{G}$ \\
\hline Cadburry Used & $100 \mathrm{G}$ \\
\hline Skimmilk Used & $350 \mathrm{G}$ \\
\hline Sugar Used & $750 \mathrm{G}$ \\
\hline Water Used & $4 \mathrm{~L}$ \\
\hline Choco Milk Made & $9600 \mathrm{ML}$ \\
\hline
\end{tabular}

Table 3: Cost of ingredients in each bottle of Choco Milk

\begin{tabular}{|l|c|}
\hline $\begin{array}{c}\text { Cost of Carabao's milk used in } 200 \mathrm{ml} \\
\text { of Choco Milk }\end{array}$ & P5.73 \\
\hline
\end{tabular}




\begin{tabular}{|c|c|}
$\begin{array}{c}\text { Cost of Carabao's milk used in 1L of } \\
\text { Choco Milk }\end{array}$ & P28.65 \\
\hline $\begin{array}{c}\text { Cost of Cadburry used in 200 ml of } \\
\text { Choco Milk }\end{array}$ & P9.875 \\
\hline $\begin{array}{c}\text { Cost of Cadburry used in 1L of Choco } \\
\text { Milk }\end{array}$ & P4.375 \\
\hline $\begin{array}{c}\text { Cost of Cornstarch used in 200 ml of } \\
\text { Choco Milk }\end{array}$ & P0.139 \\
\hline $\begin{array}{c}\text { Cost of Cornstarch used in 1L of Choco } \\
\text { Milk }\end{array}$ & P0.695 \\
\hline $\begin{array}{c}\text { Cost of Skimmmilk used in 200 ml of } \\
\text { Choco Milk }\end{array}$ & P1.24 \\
\hline $\begin{array}{c}\text { Cost of Skimmmilk used in 1L of Choco } \\
\text { Milk }\end{array}$ & P6.198 \\
\hline $\begin{array}{c}\text { Cost of Sugar used in 200 ml of Choco } \\
\text { Milk }\end{array}$ & P0.73 \\
\hline Cost of Sugar used in 1L of Choco Milk & P3.675 \\
\hline $\begin{array}{c}\text { Cost of Water used in 200 ml of Choco } \\
\text { Milk }\end{array}$ & P0.10 \\
\hline $\begin{array}{c}\text { Cost of Water used in 1L of Choco Milk } \\
\text { P0.52 }\end{array}$
\end{tabular}

\section{Materials and Methods}

The researchers used the concept of Linear Programming to maximize the profit. Linear Programming is a mathematical technique for generating and selecting the optimal or the best solution for a given objective function. It may be formally defined as a method of optimizing (minimizing and maximizing). LP model is converted in standard form: [3]

$$
\operatorname{maximize} z=c_{1} x_{1}+c_{2} x_{2}+\cdots+c_{n} x_{n}
$$

Subject to

$$
\begin{aligned}
& a_{11} x_{1}+a_{12} x_{2}+\cdots+a_{1 n} x_{n}=b_{1} \\
& a_{21} x_{1}+a_{22} x_{2}+\cdots+a_{2 n} x_{n}=b_{2} \\
& \vdots \\
& a_{m 1} x_{1}+a_{m 2} x_{2}+\cdots+a_{m n} x_{n}=b_{m}
\end{aligned}
$$

Where the variables $x_{1}, \ldots, x_{n}$ are nonnegative, and the constants $b_{1}, \ldots, b_{m}$ on the right-hand sides of the constraints are also non-negative. We can use matrix notation to represent the cost (or profit) vector $c=\left(c_{1}, c_{2}, \ldots\right.$, $\left.\mathrm{c}_{\mathrm{n}}\right)$ and the variable vector

$$
x=\left[\begin{array}{c}
x_{1} \\
x_{2} \\
\cdot \\
\cdot \\
\cdot \\
n
\end{array}\right]
$$

The coefficient matrix is

$$
A=\left[\begin{array}{ccc}
a_{11} & \cdots & a_{1 n} \\
\vdots & \ddots & \vdots \\
a_{m 1} & \cdots & a_{m n}
\end{array}\right]
$$

And the

$$
\boldsymbol{b}=\left[\begin{array}{c}
b_{1} \\
b_{2} \\
\cdot \\
\cdot \\
\cdot \\
b_{n}
\end{array}\right]
$$


Then the optimization problem can be expressed as

$$
\text { maximize } z=c x
$$

Subject to

$$
A x=b
$$

$$
\begin{aligned}
& x \geq 0 \\
& b \geq 0
\end{aligned}
$$

\subsection{MATLAB Simulink}

The Simulink toolbox is a useful software package to develop simulation models for recurrent neural network applications in the MATLAB Simulink environment. With its graphical user interface and extensive library, it provides researchers with a modern and interactive design tool build simulation models rapidly and easily.

\section{The command linprog}

The command linprog from the optimization toolbox implements the simplex algorithm to solve minimization of a linear programming problem in the form: [24]

$$
\min _{x} f^{T} x \text { s.t. }\left\{\begin{array}{c}
A \cdot x \leq b \\
A_{e q} \cdot x=b_{e q} \\
l_{b} \leq x \leq u_{b}
\end{array}\right.
$$

Where $f, x, b, b_{e q}, l_{b}$ and $u_{b}$ are vectors and $A$ and $A_{e q}$ are matrices.

The general form of linprog command is: [25]

$$
[x, f v a l, \text { exitflag, output, lambda }]=\operatorname{linprog}\left(f, A, b, A_{\text {eq }}, b_{\text {eq }}, l b, u b, x 0, \text { options }\right)
$$

Note that the linprog command tries to minimize an objective function. Tomaximize the objective function, change $f$ to $-f$ and input - fvalafter the optimal solution was found. Then take the value of $-f v a l$ as the maximum value of the objective function.

\section{Results and Discussion}

Operating expense per unit is calculated by: 1. listing the monthly operating expenses given by MADRA, and the number of unit produced of all the products monthly; 2. dividing each monthly operating expenses by the number of unit produced of all the products monthly; 3. computing for the average of the results in (2) to come up with the operating expense per unit.

Given a certain budget for all the ingredients, we divided the budget by each ingredient's amount contribution on every product made.

\section{Objective function of the Model}

To develop an objective function for each model, we define the following variables:

Let $\mathrm{R}$ be the total revenue for each model

\begin{tabular}{|c|c|c|c|}
\hline Variables & Variants & $\begin{array}{l}\text { Reta } \\
\text { il Price }\end{array}$ & Sales \\
\hline$X_{1}$ & $\begin{array}{c}\text { Fresh } \\
\text { Milk Litro }\end{array}$ & $\begin{array}{ll} & \mathrm{P} 14 \\
0 & \end{array}$ & P41,160.00 \\
\hline$X_{2}$ & $\begin{array}{c}\text { Fresh } \\
\text { Milk 200ml }\end{array}$ & $\mathrm{P} 40$ & $\mathrm{P} 23,980.00$ \\
\hline$X_{3}$ & Choco & P14 & P84,560.00 \\
\hline
\end{tabular}

$X_{1}$ Be the number of Fresh Milk Litro to be produced.

$X_{2}$ Be the number of Fresh Milk $200 \mathrm{ml}$ to be produced.

$X_{3}$ Be the number of Choco Milk Litro to be produced.

$X_{4}$ Be the number of Choco Milk $200 \mathrm{ml}$ to be produced.

$X_{5}$ Be the number of Milk O Jel $200 \mathrm{~g}$ to be produced. 


\begin{tabular}{|c|c|c|c|}
\hline & Milk Litro & \multicolumn{1}{|l|}{} & \\
\hline$X_{4}$ & $\begin{array}{c}\text { Choco } \\
\text { Milk 200ml }\end{array}$ & P40 & P58,880.00 \\
\hline$X_{5}$ & $\begin{array}{c}\text { Milk O } \\
\text { Jel 200g }\end{array}$ & P40 & P5,720.00 \\
\hline$X_{6}$ & $\begin{array}{c}\text { Milk O } \\
\text { Jel 100g }\end{array}$ & P20 & P5,460.50 \\
\hline
\end{tabular}

Table 4: Variants, Retail Price and Sales of MADRA from March to December

The retail price of each variants. It also shows the revenue of MADRA for each variant from March to December 2017. The 1 liter of Choco Milk has the largest sales of P84,560.00, next to it as the second highest earning revenue of P58,880.00 is the Choco Milk 200ml variant. Followed by the 1 liter of Fresh Milk which has a P41,160.00 of revenue. The Fresh Milk 200ml variant has P23,980.00 which will be placed as the third to the lowest earning revenue. And the second to the lowest earning revenue is the Milk O Jel $100 \mathrm{~g}$ variant, which is P5,720.00, while the 100g of Milk O Jel has the smallest sales of P5,460.00.

\subsection{Constraints of the Model}

The model requires different set of constraints to obtain the maximum profit of Magdalena Dairy Raisers Association. In this section, we identify the different constraints of each product by variants.

Table 5: Cost of Ingredients and Available Budget of Choco Milk

\begin{tabular}{|c|c|c|c|}
\hline $\begin{array}{l}\text { Constraints/ } \\
\text { Variables }\end{array}$ & $X_{3}$ & $X_{4}$ & $\begin{array}{l}\text { Available } \\
\text { Budget }\end{array}$ \\
\hline $\begin{array}{l}\text { Carabao's } \\
\text { Milk }\end{array}$ & $5^{28.6}$ & 5.73 & P1600.00 \\
\hline Cadbury & 4.38 & 0.88 & P300.00 \\
\hline Cornstarch & 0.69 & 0.14 & P50.00 \\
\hline Skim milk & 6.2 & 1.24 & P375.00 \\
\hline Sugar & 3.67 & 0.73 & P225.00 \\
\hline Water & 0.52 & 0.1 & P50.00 \\
\hline $\begin{array}{l}\text { Labelled } \\
\text { Bottle }\end{array}$ & 14.9 & 8.71 & P1250.00 \\
\hline $\begin{array}{l}\text { Operating } \\
\text { Expense }\end{array}$ & 8.51 & 8.51 & P608.04 \\
\hline
\end{tabular}

The cost of ingredients and other expenses for Choco Milk. The available budget for Carabao's Milk is P1,600.00, P300.00 for Cadburry, P50.00 for Cornstarch, P375.00 for Skim Milk, P225.00 for Sugar, P50 for water, P1,250.00 for Labelled Bottle and P608.04 for operating expense.

\subsection{Linear Programming Model for Choco Milk}

Maximize $\quad R=140 X_{3}+40 X_{4}$

Subject to

Cost of

Cost

$$
28.65 X_{3}+5.73 X_{4} \leq 1600
$$

Cost

$$
4.38 X_{3}+0.88 X_{4} \leq 300
$$

Cost

$$
0.43 X_{3}+0.09 X_{4} \leq 50
$$

of

$$
6.2 X_{3}+1.24 X_{4} \leq 375
$$

Skim

milk 

Cost
of$$
3.67 X_{3}+0.73 X_{4} \leq 225
$$
Sugar
Cost
of
Water$$
0.52 X_{3}+0.1 X_{4} \leq 50
$$
Cost
of
Labelled
Bottle
Cost

$$
14.9 X_{3}+8.71 X_{4} \leq 1250
$$
of
Operating

$$
8.51 X_{3}+8.51 X_{4} \leq 608.04
$$
Expense

Table 6: Optimal Solution for Choco Milk

The Optimal Solution for Choco Milk. With the help MATLAB, the result shows that the proposed number of productions for 1 liter of Choco Milk is 52 units while the proposed number of productions for $200 \mathrm{ml}$ of Choco Milk is 20 units. Hence MADRA can obtain a maximum revenue of P8,052.93. MADRA can obtain an approximate revenue for Choco Milk of P161,040.00 for ten months or 20 times of production

The optimality range of the coefficients of each decision variables in the objective function. It shows that the current solution will remain optimal if the profit contribution in the production of 1 Liter and 200ml variety of Choco milk will be on the range $(40,200)$ and $(28,140)$ respectively.

\begin{tabular}{|c|c|c|c|}
\hline Constraints/Variables & $X_{3}$ & $X_{4}$ & $\mathrm{R}$ \\
\hline Carabao's Milk & $65^{28 .}$ & $73^{5 .}$ & P1600.00 \\
\hline Cadburry & $8^{4.3}$ & $8_{8}{ }^{0 .}$ & P300.00 \\
\hline Cornstarch & $\begin{array}{ll} & 0.4 \\
3 & \end{array}$ & $09^{0 .}$ & P50.00 \\
\hline Skim milk & 6.2 & $24^{1 .}$ & P375.00 \\
\hline Sugar & $\begin{array}{ll} & 3.6 \\
7 & \end{array}$ & $73^{0 .}$ & P225.00 \\
\hline Water & $\begin{array}{ll} & 0.5 \\
2 & \end{array}$ & $\begin{array}{ll} & 0 . \\
1 & \end{array}$ & P50.00 \\
\hline Labelled Bottle & $\begin{array}{ll} & 14 . \\
9 & \end{array}$ & $71^{8 .}$ & $\mathrm{P} 1250.00$ \\
\hline Operating Expense & $\begin{array}{ll} & 8.5 \\
1 & \end{array}$ & $51^{8 .}$ & P608.04 \\
\hline Objective Function & 52 & $0^{2}$ & P8,052.93 \\
\hline
\end{tabular}

Table 7: Optimality Range for Choco Milk 


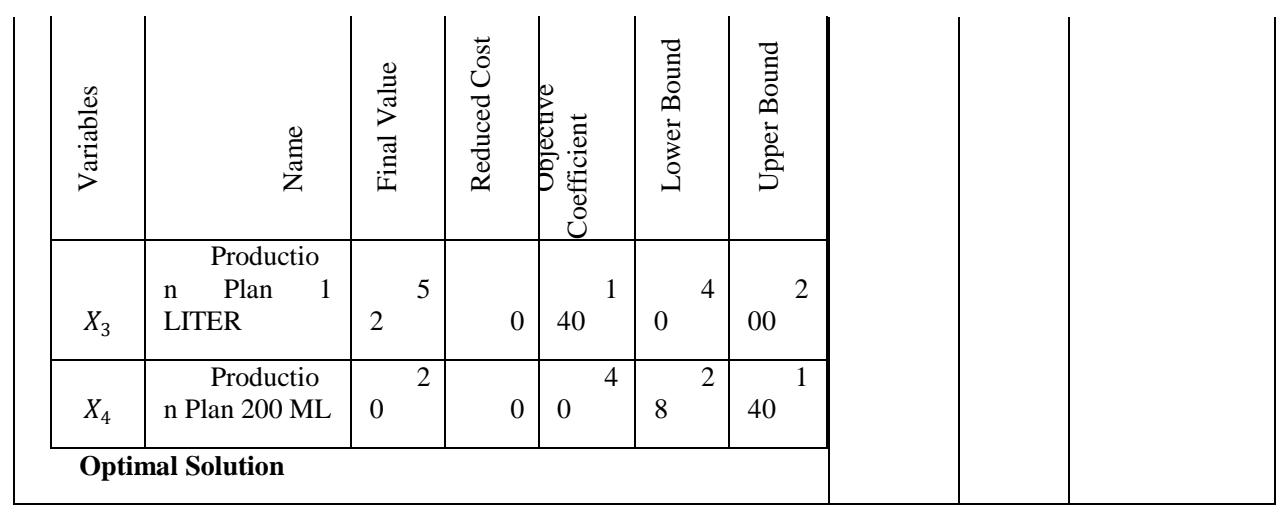

Table 8: Feasibility Range for Choco Milk

\begin{tabular}{|c|c|c|c|c|c|}
\hline \multicolumn{6}{|l|}{ Constraints } \\
\hline $\begin{array}{l}\text { Ẽ } \\
\text { Z }\end{array}$ & 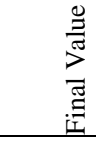 & 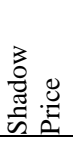 & 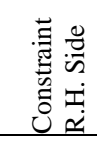 & 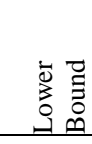 & 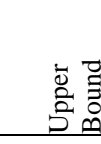 \\
\hline $\begin{array}{l}\text { Cadburry } \\
\text { Used }\end{array}$ & 244.69 & 0 & 300 & 244.69 & $\infty$ \\
\hline $\begin{array}{l}\text { Cornstarch } \\
\text { Used }\end{array}$ & 24.09 & 0 & 50 & 24.09 & $\infty$ \\
\hline $\begin{array}{l}\text { Skimmilk } \\
\text { Used }\end{array}$ & 346.25 & 0 & 375 & 346.25 & $\infty$ \\
\hline Sugar Used & 204.88 & 0 & 225 & 204.88 & $\infty$ \\
\hline $\begin{array}{l}\text { Water } \\
\text { Used }\end{array}$ & 28.96 & 0 & 50 & 28.96 & $\infty$ \\
\hline $\begin{array}{l}\text { Labelled } \\
\text { Bottle } \\
\text { Used }\end{array}$ & 944.05 & 0 & 1250 & 944.05 & $\infty$ \\
\hline $\begin{array}{l}\text { Operating } \\
\text { Expense } \\
\text { Used }\end{array}$ & 608.04 & 1.76 & 608.04 & 475.09 & 971.43 \\
\hline $\begin{array}{l}\text { Carabao's } \\
\text { Milk Used }\end{array}$ & 1600 & 4.36 & 1600 & 569.99 & 1732.86 \\
\hline
\end{tabular}

The feasibility range of each constraints in producing $1 \mathrm{~L}$ and $200 \mathrm{ml}$ of Choco milk. Per unit of decrease in the cost of Operating expense and Carabao's Milk, the maximum revenue will decrease by 1.76 and 4.36 per unit within the interval $[475.09,971.43]$ and $[569.99,1732.863]$ respectively. However, either we increase or decrease the cost of labelled bottle, cadburry, cornstarch, skimmilk, sugar and water, the maximum revenue will not change, or the solution will still be feasible.

\section{Conclusion}

The researchers were able to utilize the use of cost optimization using a mathematical model where we found out that there are several applicable ways to get a higher profit. The Magdalena Dairy Raisers Association sells dairy products such as: Fresh Milk, Choco Milk, and Milk O Jel. Using the Linear Programming Model, we obtain the total revenue of each dairy product with an increase of $108.17 \%$ for Fresh Milk $12.10 \%$ for Choco Milk, and $35.95 \%$ for Milk O Jel from their previous revenue. As a result, we achieved our goal to maximize the net profit with a total increase of $151.12 \%$

\section{References}

http://www.investorwords.com/article/ revenue-vs-profit.html

R. OFarrell, Advantages and Disadvantages of Profit Maximization 
Taha, Hamdy, Operations Research, 8th Edition, Person Prentice Hall, Upper Saddle River, New Jersey. ISBN: 0-13-188923-0 